\title{
Polymorphisms of interleukin 6 in Down syndrome individuals: a case-control study
}

\author{
M.F. Mattos ${ }^{1}$, L. Uback ${ }^{1}$, P.M. Biselli-Chicote ${ }^{1}$, J.M. Biselli², \\ E.M. Goloni-Bertollo ${ }^{1}$ and E.C. Pavarino ${ }^{1}$ \\ ${ }^{1}$ Unidade de Pesquisa em Genética e Biologia Molecular, \\ Faculdade de Medicina de São José do Rio Preto, \\ São José do Rio Preto, SP, Brasil \\ ${ }^{2}$ Instituto de Biociências Letras e Ciências Exatas, \\ Universidade Estadual Paulista, Câmpus São José do Rio Preto, \\ São José do Rio Preto, SP, Brasil \\ Corresponding author: E.C. Pavarino \\ E-mail: erika@famerp.br \\ Genet. Mol. Res. 16 (3): gmr16039738 \\ Received May 25, 2017 \\ Accepted July 21, 2017 \\ Published August 17, 2017 \\ DOI http://dx.doi.org/10.4238/gmr16039738 \\ Copyright (C) 2017 The Authors. This is an open-access article distributed under the terms of \\ the Creative Commons Attribution ShareAlike (CC BY-SA) 4.0 License.
}

\begin{abstract}
Down syndrome (DS) individuals present impaired adaptive immune system. However, the etiology of the immunological deficiency in these individuals is not completely understood. This study investigated the frequency of interleukin 6 polymorphisms (rs 1800795, rs1800796, and rs1800797) in individuals with DS and individuals without the syndrome. The study included 282 individuals, 94 with DS attended at the General Genetics Outpatient Service of Hospital de Base, São José do Rio Preto, SP, Brazil, and 188 individuals without DS attended at the Pediatric Service of Hospital de Base de São José do Rio Preto, SP, Brazil. Genotyping was performed by allelic discrimination technique by real-time polymerase chain reaction using TaqMan SNP Genotyping Assays (Applied Biosystems). There was no difference in the genotype frequency between individuals with and without DS for the evaluated polymorphisms $(\mathrm{P}>0.05)$. The frequency of interleukin
\end{abstract}

Genetics and Molecular Research 16 (3): gmr16039738 
6 polymorphisms did not differ significantly between individuals with and without DS in the casuistic analyzed.

Key words: Down syndrome; Trisomy 21; Genetic polymorphism; Interleukin 6

\section{INTRODUCTION}

Down syndrome (DS) or trisomy 21 is a common chromosomal disorder among liveborn infants (1:700 live births) (Jorde et al., 2015). Individuals with DS present an impairment of adaptive immune system, with reduced level of lymphocytes (Kusters et al., 2009) and an increase in the susceptibility to infections and autoimmune diseases (Gillespie et al., 2006).

Previous studies reported by our group showed differential expression of genes involved in the immunological and inflammatory processes in DS individuals, which could explain the immunological deficiencies observed in these individuals. Genes with significant high expression include CD52, RANTES, CCR2, BCL2L1, IL10, and CCR5, and genes with reduced expression were CD46, FOS, BCL2, CCL3, IL6, EDN1, CD40LG, CD80, CCR7, IKBKB, CD28, NOS2, CD19, CD40, SKI, BDKRB1, and LTA4H (Sommer et al., 2008; Zampieri et al., 2014; Silva et al., 2016).

Research in DS has shown that the 21 trisomy is associated with a reduction of $\mathrm{T}$ and $\mathrm{B}$ cells, alteration in differentiation and maturation of B cells, and activation of the Th1 and Th2 cells (Guazzarotti et al., 2009; Carsetti et al., 2015; Schoch et al., 2017). DS also present functional and morphological alterations of the thymus that is smaller (Kusters et al., 2009; Lorenzo et al., 2013), possibly as a result of the increase of cytokines as gamma-interferon (gamma-IFN), and tumor necrosis factor (alpha-TNF) (Murphy et al., 1992).

The cytokines play a role in the regulation of growth and differentiation of lymphocytes, activation and regulation of inflammatory cells as mast cells, neutrophils and eosinophils, and communication among the immunological system cells (Abbas et al., 2014). This protein class is classified in interleukins (IL), TNF, chemokines (chemotactic cytokines), IFN, and growth mesenchymal factor (Beaulieu et al., 2010). The cytokines IL1, IL2, IL6, IL7, IL8, IL12, IL17, TNF, and gamma-IFN are considered pro-inflammatory, and the cytokines IL4, IL10, IL13, and transforming growth factor-beta play an anti-inflammatory role (Beaulieu et al., 2010).

Studies in DS individuals have shown increased serum levels of IL4 and IL10 and decreased serum levels of IL6 and alpha-TNF compared with children without the syndrome (Cetiner et al., 2010). Furthermore, an increase in the production of alpha-TNF, beta-IL1, -IL6, -IL8, alpha-INF, gamma-INF, and IL10 was observed in peripheral blood culture of DS children, stimulated by influenza A virus and by Streptococcus pneumoniae (Broers et al., 2012, 2014). A significant increase in IL7 serum levels in healthy adolescents with DS was observed, and peripheral blood mononuclear cells from these individuals stimulated with phytohemagglutinin (PHA) and cytomegalovirus (CMV) presented an increase of gammaIFN and IL10 levels (Guazzarotti et al., 2009). The increase of the beta-IL1, -IL4, -IL6, -IL10, -IL12, gamma-IFN, and alpha-TNF levels and cytokines produced by T-helper cells (Th1, Th2, and Th17) was also observed in gingival crevicular fluid of DS adolescents compared with individuals without DS (Tsilingaridis et al., 2012).

The IL6 gene is located on the short arm of chromosome $7(7 \mathrm{p} 21)$ and presents three important polymorphisms in the promoter region: $-174 \mathrm{G}>\mathrm{C}$ ( $\mathrm{rs} 1800795),-572 \mathrm{G}>\mathrm{C}$

Genetics and Molecular Research 16 (3): gmr16039738 
(rs1800796), and -597G $>$ A (rs1800797). The polymorphism $-174 \mathrm{G}>\mathrm{C}$ has an influence on the transcriptional regulation of the IL 6 and is associated with the levels of this cytokine (Wang et al., 2017). The allele IL6 $-572 G$ was associated with increased IL6 serum levels in patients undergoing post-percutaneous coronary intervention restenosis (Gao et al., 2013) and coronary heart disease susceptibility (Zhang et al., 2017). A study also observed that smokers and non-smokers carrier the IL6 -572GG genotype and present increased levels of this protein (Shin et al., 2007). Chou et al. (2016) found that the polymorphism IL6 -597G>A may be associated with susceptibility and severity of community-acquired pneumonia (CAP). The present study investigated the frequency of three genetic polymorphisms in the IL6 gene (rs15800795, rs15800796, and rs15800797) in DS individuals and without the syndrome, aiming to identify differences between the groups that could be associated with the clinical conditions of the syndrome.

\section{MATERIAL AND METHODS}

\section{Subjects}

The Research Ethics Committee of Faculdade de Medicina de São José do Rio Preto FAMERP (No. 427.782; CAAE No. 20112313.9.0000.5415) formally approved the study. The study included 282 individuals, 94 DS children with trisomy 21 (case group), from the General Genetics Outpatient Service of Hospital de Base, São José do Rio Preto, SP, Brazil, and 188 individuals without DS (control group) from the Pediatric Service of Hospital de Base de São José do Rio Preto, SP, Brazil.

The group case consisted of 51 males and 43 females with a mean age of 4.3 years (ranging from 1 to 30 years of age) and the control group included 96 males and 92 females with a mean age of 4.4 years (ranging from 1 to 14 years of age).

\section{Genotyping analysis}

DNA isolation was performed from peripheral blood (Salazar et al., 1998). The genotyping of the polymorphisms was performed using the TaqMan Allele Discrimination Assay (Applied Biosystems), following manufacturer's instruction. Table 1 presents the specific assays for each polymorphism evaluated. The reactions were performed on StepOne Plus RealTime PCR System (Applied Biosystems) and cycled following manufacturer's instructions.

Table 1. Taqman assays (Applied Biosystems) for genotyping of the polymorphisms by allele discrimination.

\begin{tabular}{l|c|c}
\hline Polymorphism (rs*) & Substitution & Taqman Assay ID \\
\hline IL6 rs 1800795 & $G \rightarrow C$ & C 1839697_20 \\
\hline IL6 rs 1800796 & $G \rightarrow C$ & C_111326893_10 \\
\hline IL6 rs 1800797 & $G \rightarrow A$ & C_ 1839695_20 \\
\hline
\end{tabular}

*http://www.ncbi.nlm.nih.gov/projects/SNP/.

\section{Statistical analysis}

The allele frequencies of the polymorphisms were evaluated for Hardy-Weinberg (HWE) equilibrium by the chi-square test using the BioEstat software version 5.0. The

Genetics and Molecular Research 16 (3): gmr16039738 
genotype distribution between the groups was evaluated in the codominant, dominant, recessive, overdominant, and additive model, using the SNPStats software (http://bioinfo. iconcologia.net/SNPstats_web) program. Values of $\mathrm{P} \leq 0.05$ were considered significant.

\section{RESULTS}

The allele frequencies of the polymorphisms $-174 \mathrm{G}>\mathrm{C}$ ( $\mathrm{rs} 1800795),-572 \mathrm{G}>\mathrm{C}$ (rs1800796), and $-597 \mathrm{G}>\mathrm{A}$ ( $\mathrm{rs} 1800797)$ were in HWE in case and control groups $(\mathrm{P}=0.8$ and $\mathrm{P}=0.57$ for $-174 \mathrm{G}>\mathrm{C} ; \mathrm{P}=1$ and $\mathrm{P}=0.49$ for $-572 \mathrm{G}>\mathrm{C} ; \mathrm{P}=1$ and $\mathrm{P}=1$ for $-597 \mathrm{G}>\mathrm{A}$ ) (Table 2). There was no difference in the genotype distribution between the groups with DS and without the syndrome $(\mathrm{P}>0.05)$ (Table 3$)$.

Table 2. Allele frequencies of $-174 \mathrm{G}>\mathrm{C}$ ( $\mathrm{rs} 1800795),-572 \mathrm{G}>\mathrm{C}$ ( $\mathrm{rs} 1800796)$, and $-597 \mathrm{G}>\mathrm{A}$ ( $\mathrm{rs} 1800797)$ polymorphisms.

\begin{tabular}{l|c|c|c}
\hline Polymorphism & Allele & Case & Control \\
\hline$-174 \mathrm{G}>\mathrm{C}(\mathrm{rs} 1800795)$ & $C$ & 0.27 & 0.26 \\
\hline$-572 \mathrm{G}>\mathrm{C}(\mathrm{rs} 1800796)$ & $C$ & 0.10 & 0.12 \\
\hline$-597 \mathrm{G}>\mathrm{A}(\mathrm{rs} 1800797)$ & $A$ & 0.26 & 0.27 \\
\hline
\end{tabular}

Table 3. Genotype distribution of $-174 \mathrm{G}>\mathrm{C}$ ( $\mathrm{rs} 1800795)$, $-572 \mathrm{G}>\mathrm{C}$ (rs1800796), and $-597 \mathrm{G}>\mathrm{A}$ ( $\mathrm{rs} 1800797)$ polymorphisms between the groups with DS (case) and without the syndrome (control).

\begin{tabular}{|c|c|c|c|c|c|}
\hline Model & Genotype & Control group & Case group & OR $(95 \% \mathrm{CI})$ & P value \\
\hline \multicolumn{6}{|c|}{ Interleukin 6 -597G $>A($ rs1800797) } \\
\hline \multirow[t]{3}{*}{ Codominant } & $G G$ & $100(53.2 \%)$ & $52(55.3 \%)$ & 1.00 & \multirow[t]{3}{*}{0.96} \\
\hline & $A G$ & $75(39.9 \%)$ & $36(38.3 \%)$ & $1.07(0.63-1.80)$ & \\
\hline & $A A$ & $13(6.9 \%)$ & $6(6.4 \%)$ & $1.12(0.40-3.12)$ & \\
\hline \multirow[t]{2}{*}{ Dominant } & $G G$ & $100(53.2 \%)$ & $52(55.3 \%)$ & 1.00 & \multirow[t]{2}{*}{0.78} \\
\hline & $A G-A A$ & $88(46.8 \%)$ & $42(44.7 \%)$ & $1.07(0.65-1.77)$ & \\
\hline \multirow[t]{2}{*}{ Recessive } & $G G-A G$ & $175(93.1 \%)$ & $88(93.6 \%)$ & 1.00 & \multirow[t]{2}{*}{0.86} \\
\hline & $A A$ & $13(6.9 \%)$ & $6(6.4 \%)$ & $1.09(0.40-2.97)$ & \\
\hline \multirow[t]{2}{*}{ Overdominant } & $G G-A A$ & $113(60.1 \%)$ & $58(61.7 \%)$ & 1.00 & \multirow[t]{2}{*}{0.85} \\
\hline & $A G$ & $75(39.9 \%)$ & $36(38.3 \%)$ & $1.05(0.63-1.76)$ & \\
\hline Log-additive & - & - & - & $1.06(0.71-1.59)$ & 0.77 \\
\hline \multicolumn{6}{|c|}{ Interleukin 6 -174G $>C$ (rs1800795) } \\
\hline \multirow[t]{3}{*}{ Codominant } & $G G$ & $100(53.2 \%)$ & $49(52.1 \%)$ & 1.00 & \multirow[t]{3}{*}{0.97} \\
\hline & $G C$ & $77(41 \%)$ & $39(41.5 \%)$ & $0.95(0.57-1.60)$ & \\
\hline & $C C$ & $11(5.8 \%)$ & $6(6.4 \%)$ & $0.89(0.31-2.56)$ & \\
\hline \multirow[t]{2}{*}{ Dominant } & $G G$ & $100(53.2 \%)$ & $49(52.1 \%)$ & 1.00 & \multirow[t]{2}{*}{0.82} \\
\hline & $G C-C C$ & $88(46.8 \%)$ & $45(47.9 \%)$ & $0.94(0.57-1.56)$ & \\
\hline \multirow[t]{2}{*}{ Recessive } & $G G-G C$ & $177(94.2 \%)$ & $88(93.6 \%)$ & 1.00 & \multirow[t]{2}{*}{0.86} \\
\hline & $C C$ & $11(5.8 \%)$ & $6(6.4 \%)$ & $0.91(0.33-2.55)$ & \\
\hline \multirow[t]{2}{*}{ Overdominant } & $G G-C C$ & $111(59 \%)$ & $55(58.5 \%)$ & 1.00 & \multirow[t]{2}{*}{0.89} \\
\hline & $G C$ & $77(41 \%)$ & $39(41.5 \%)$ & $0.96(0.58-1.60)$ & \\
\hline Log-additive & - & - & - & $0.95(0.63-1.43)$ & 0.80 \\
\hline \multicolumn{6}{|c|}{ Interleukin $6-572 \mathrm{G}>\mathrm{C}(\mathrm{rs} 1800796)$} \\
\hline \multirow[t]{3}{*}{ Codominant } & $G G$ & $146(77.7 \%)$ & $76(80.8 \%)$ & 1.00 & \multirow[t]{3}{*}{0.69} \\
\hline & $G C$ & $38(20.2 \%)$ & $17(18.1 \%)$ & $1.18(0.63-2.24)$ & \\
\hline & $C C$ & $4(2.1 \%)$ & $1(1.1 \%)$ & $2.12(0.23-19.29)$ & \\
\hline \multirow[t]{2}{*}{ Dominant } & $G G$ & $146(77.7 \%)$ & $76(80.8 \%)$ & 1.00 & \multirow[t]{2}{*}{0.50} \\
\hline & $G C-C C$ & $42(22.3 \%)$ & $18(19.2 \%)$ & $1.24(0.66-2.30)$ & \\
\hline \multirow[t]{2}{*}{ Recessive } & $G G-G C$ & $184(97.9 \%)$ & $93(98.9 \%)$ & 1.00 & \multirow[t]{2}{*}{0.50} \\
\hline & $C C$ & $4(2.1 \%)$ & $1(1.1 \%)$ & $2.04(0.23-18.57)$ & \\
\hline \multirow[t]{2}{*}{ Overdominant } & $G G-C C$ & $150(79.8 \%)$ & $77(81.9 \%)$ & 1.00 & \multirow[t]{2}{*}{0.63} \\
\hline & $G C$ & $38(20.2 \%)$ & $17(18.1 \%)$ & $1.17(0.62-2.21)$ & \\
\hline Log-additive & - & - & - & $1.25(0.71-2.18)$ & 0.43 \\
\hline
\end{tabular}

Genetics and Molecular Research 16 (3): gmr16039738 


\section{DISCUSSION}

Alteration in the immune system, such as functional and morphological thymus abnormalities (Bloemers et al., 2011; Karl et al., 2012), lymphocytopenia, and alteration in differentiation, maturation, and activation of the T lymphocyte (Guazzarotti et al., 2009; Lorenzo et al., 2013) is frequently observed in DS individuals (Kusters et al., 2009). It can be responsible for increased incidence of infections, mainly in the respiratory tract (Bloemers et al., 2010; Broers et al., 2012), and occurrence of autoimmune disease in DS (Gillespie et al., 2006; Pellegrini et al., 2012).

The physiopathology of various infections involving the immunological system has the inflammation as a common factor (Trotta, 2009). The cytokines belong to a diversified group of protein, which participated in various biological processes, including the mediation of the inflammatory response (Zhang and An, 2007). Changes in the concentration of proinflammatory and anti-inflammatory cytokines in DS individuals demonstrate its association with the syndrome pathogenesis (Tsilingaridis et al., 2003; Guazzarotti et al., 2009; Cetiner et al., 2010; Broers et al., 2012, 2014). The study of Cetiner et al. (2010) observed that the IL6 serum levels were lower in DS children compared with individuals without the syndrome. The authors proposed that the reduced levels of this cytokine possibly difficult the proliferation and function of macrophages and other phagocytes, what could explain the reason for the recurrent infections observed in DS.

Considering that changes in the cytokine concentration may be due to genetic polymorphisms, our study investigated the frequency of $-174 \mathrm{G}>\mathrm{C}$ ( $\mathrm{rs} 1800795),-572 \mathrm{G}>\mathrm{C}$ (rs1800796), and -597G $>$ A (rs1800797) polymorphisms in DS children and without the syndrome, aiming to identify differences between groups that may be associated with clinical manifestations of the syndrome. Our results showed no difference in genotype distribution between individuals with and without DS for the polymorphisms evaluated.

In our study, the $-174 C$ allele frequency was 0.27 in the case group and 0.26 in the control group. These frequencies are different from those observed in other ethnic groups, varying of 0.40 in Europeans from the United Kingdom, 0.15 in Gujarati Indian, and 0.05 in the Afro-Caribbean (Fishman et al., 1998). In Brazilians, the study of Vicari et al. (2015) showed a $C$ allele frequency of 0.14 in patients with anemia and 0.15 in the control group. Teixeira et al. (2014) observed similar frequencies in individuals with periodontitis $(0.15)$ and the control group (0.17). Interestingly, the allele frequency of this polymorphism was different between three ethnic groups of the Brazilian population presenting a $C$ allele frequency of $14.5 \%$ in northeast region patients (descendant of Africans and Portuguese), 36.7\% in South region (descendant of Germans), and 2.5\% in Amerindian from Tiriyó tribe (Gadelha et al., 2005).

In our study, the $-174 G G$ genotype was the most frequent in the case group (52.1\%) and the control group (53.2\%). The GC genotype frequency was $41.5 \%$ in the case group and $41 \%$ in the control group. The frequency of the $C C$ genotype was $6.4 \%$ in the case group and $5.8 \%$ in the control group. Teixeira et al. (2014) showed a $G G$ genotype frequency of 76.1 and $69.4 \%$ for the case and control groups, respectively, in patients with periodontitis in the Brazilian population. The frequency of the heterozygous genotype $G C$ was $17.2 \%$ in the case group and $27.6 \%$ in the control group, while the genotype $C C$ was $6.7 \%$ in the case group and $3.1 \%$ in the control group. Vicari et al. (2015) observed in Brazilians with sickle-cell anemia that the genotype $G G$ was most frequent in the case (74\%) and the control (75\%) groups. The $G C$ genotype presented frequency of 24 and $20 \%$ in both groups, and the genotype $C C$ was present in only $2 \%$ of the case individuals and $5 \%$ of the control group.

Genetics and Molecular Research 16 (3): gmr16039738 
Regarding the $-572 \mathrm{G}>\mathrm{C}$ (rs 1800796) polymorphism, a study performed in Sweden with myocardial infarction individuals did not find the $C C$ genotype and detected high prevalence of the $G G$ genotype (92\%), while the heterozygous genotype $G C$ was present in $8 \%$ of the patients with acute myocardial infarction treated with thrombolysis (Bennermo et al., 2004). Our study also observed higher frequency of the $G G$ genotype ( $80.8 \%$ in the case group and $77.7 \%$ in the control group) and low frequency of the $C C$ genotype (1.1\% in the case group and $2.1 \%$ in the control group); the frequency of the heterozygous genotype $C G$ was $18.1 \%$ in the case group and $20.2 \%$ in the control group. In the Brazilian population, the $C C$ genotype was not present among patients with anemia, and only $3 \%$ of the control individuals showed these genotypes (Vicari et al., 2015). These authors also found higher frequency of the $G G$ genotype in the case $(78 \%)$ and control group $(68 \%)$. On the other hand, a study performed with the Korean population observed prevalence of the genotype $C C(57 \%)$, while the $G C$ and $G G$ genotypes showed frequencies of 36.2 and 6.8\%, respectively (Shin et al., 2007).

Our study showed similar frequencies of the $597 \mathrm{G}>\mathrm{A}$ (rs 1800797) polymorphism in both groups (case and control) for the $G$ allele ( 0.74 and 0.73 ) and for the $A$ allele ( 0.26 and $0.27)$. The $G$ allele was also most frequent in a Pakistani population with macular degeneration ( $G$ Allele: 0.96 and $A$ allele: 0.04 ) and in the control group ( $G$ allele: 0.82 and A allele: 0.18 ) (Ambreen et al., 2015). A study in a Chinese population showed that the frequency of the $G$ allele was $99.48 \%$, and the $A$ allele was $0.52 \%$ (Gao et al., 2014). The study performed by Vicari et al. (2015) in the Brazilian population showed that the frequency of the polymorphic $A$ allele was $15 \%$ in anemia patients and $17 \%$ in the control group.

These variations in allele and genotype frequencies among the studies may be due to the genetic origins. The Brazilian population is heterogeneous, and this heterogeneity is a result of crosses between European, African, and Amerindian (Alves-Silva et al., 2000). Allele frequencies vary among the populations probably because of the genetic drift or the adaptation to particular environmental factors (Pena et al., 2011).

In conclusion, in the population evaluated there is no evidence of difference between groups of individuals with DS and without the syndrome for $-174 \mathrm{G}>\mathrm{C}$ (rs1800795), $-572 \mathrm{G}>\mathrm{C}$ (rs1800796), and -597G $>$ A (rs1800797) polymorphisms. However, this may be the result of the reduced sample size, being necessary other studies to better understanding the contribution of these genetic polymorphisms in the modulation of the risk for immunological alterations in DS individuals.

\section{ACKNOWLEDGMENTS}

Research supported by Conselho Nacional de Desenvolvimento Científico e Tecnológico (CNPq - \#PIBIC 2014-2015), Fundação de Amparo à Pesquisa do Estado de São Paulo (FAPESP, \#2014/26218-5), and Fundação de Apoio à Pesquisa e Extensão de São José do Rio Preto - FAPERP (\#21/2015). The authors thank Faculdade de Medicina de São José do Rio Preto (FAMERP) and Hospital de Base, São José do Rio Preto, SP, Brazil, and gratefully acknowledge the assistance of Alexandre Lins Werneck in English language.

\section{REFERENCES}

Abbas AK, Lichtman AH and Pillai S (2014). Cellular and Molecular Immunology. 8th edn. Elsevier Health Sciences. Philadelphia.

Genetics and Molecular Research 16 (3): gmr16039738 
Alves-Silva J, da Silva Santos M, Guimarães PE, Ferreira AC, et al. (2000). The ancestry of Brazilian mtDNA lineages. Am. J. Hum. Genet. 67: 444-461. https://doi.org/10.1086/303004

Ambreen F, Ismail M and Qureshi IZ (2015). Association of gene polymorphism with serum levels of inflammatory and angiogenic factors in Pakistani patients with age-related macular degeneration. Mol. Vis. 21: 985-999.

Beaulieu P, Lussier D, Porreca F and Dickenson A (2010). Pharmacology of Pain. 1st edn. IASP Press. Seattle.

Bennermo M, Held C, Green F, Strandberg LE, et al. (2004). Prognostic value of plasma interleukin-6 concentrations and the $-174 \mathrm{G}>\mathrm{C}$ and $-572 \mathrm{G}>\mathrm{C}$ promoter polymorphisms of the interleukin-6 gene in patients with acute myocardial infarction treated with thrombolysis. Atherosclerosis 174: 157-163. https://doi.org/10.1016/j. atherosclerosis.2004.01.019

Bloemers BL, Bont L, de Weger RA, Otto SA, et al. (2011). Decreased thymic output accounts for decreased naive T cell numbers in children with Down syndrome. J. Immunol. 186: 4500-4507. https://doi.org/10.4049/jimmunol.1001700

Bloemers BL, Broers CJ, Bont L, Weijerman ME, et al. (2010). Increased risk of respiratory tract infections in children with Down syndrome: the consequence of an altered immune system. Microbes Infect. 12: 799-808. https://doi. org/10.1016/j.micinf.2010.05.007

Broers CJ, Gemke RJ, Morré SA, Weijerman ME, et al. (2014). Increased production of interleukin-10 in children with Down syndrome upon ex vivo stimulation with Streptococcus pneumoniae. Pediatr. Res. 75: 109-113. https://doi. org/10.1038/pr.2013.173

Broers CJ, Gemke RJ, Weijerman ME, van der Sluijs KF, et al. (2012). Increased pro-inflammatory cytokine production in Down Syndrome children upon stimulation with live influenza A virus. J. Clin. Immunol. 32: 323-329. https://doi. org/10.1007/s10875-011-9625-4

Carsetti R, Valentini D, Marcellini V, Scarsella M, et al. (2015). Reduced numbers of switched memory B cells with high terminal differentiation potential in Down syndrome. Eur. J. Immunol. 45: 903-914. https://doi.org/10.1002/ eji.201445049

Cetiner S, Demirhan O, Inal TC, Tastemir D, et al. (2010). Analysis of peripheral blood T-cell subsets, natural killer cells and serum levels of cytokines in children with Down syndrome. Int. J. Immunogenet. 37: 233-237. https://doi. org/10.1111/j.1744-313X.2010.00914.X

Chou SC, Ko HW and Lin YC (2016). CRP/IL-6/IL-10 Single-Nucleotide Polymorphisms Correlate with the Susceptibility and Severity of Community-Acquired Pneumonia. Genet. Test. Mol. Biomarkers 20: 732-740. https://doi.org/10.1089/ gtmb.2016.0156

Fishman D, Faulds G, Jeffery R, Mohamed-Ali V, et al. (1998). The effect of novel polymorphisms in the interleukin-6 (IL-6) gene on IL-6 transcription and plasma IL-6 levels, and an association with systemic-onset juvenile chronic arthritis. J. Clin. Invest. 102: 1369-1376. https://doi.org/10.1172/JCI2629

Gadelha SR, Alcantara LC, Costa GC, Rios DL, et al. (2005). Ethnic differences in the distribution of interleukin-6 polymorphisms among three Brazilian ethnic groups. Hum. Biol. 77: 509-514. https://doi.org/10.1353/hub.2005.0061

Gao J, Liu Y, Cui RZ, Mao YM, et al. (2013). Relationship of interleukin-6-572C/G promoter polymorphism and serum levels to post-percutaneous coronary intervention restenosis. Chin. Med. J. (Engl.) 126: 1019-1025.

Gao SP, Liang S, Pan M, Sun RL, et al. (2014). Interleukin-6 genotypes and serum levels in Chinese Hui population. Int. J. Clin. Exp. Med. 7: 2851-2857.

Gillespie KM, Dix RJ, Williams AJ, Newton R, et al. (2006). Islet autoimmunity in children with Down's syndrome. Diabetes 55: 3185-3188. https://doi.org/10.2337/db06-0856

Guazzarotti L, Trabattoni D, Castelletti E, Boldrighini B, et al. (2009). T lymphocyte maturation is impaired in healthy young individuals carrying trisomy 21 (Down syndrome). Am. J. Intellect. Dev. Disabil. 114: 100-109. https://doi. org/10.1352/2009.114.100-109

Jorde LB, Carey JC and Bamshad MJ (2015). Medical genetics. 5th edn. Elsevier, Philadelphia.

Karl K, Heling KS, Sarut Lopez A, Thiel G, et al. (2012). Thymic-thoracic ratio in fetuses with trisomy 21, 18 or 13. Ultrasound Obstet. Gynecol. 40: 412-417. https://doi.org/10.1002/uog.11068

Kusters MA, Verstegen RH, Gemen EF and de Vries E (2009). Intrinsic defect of the immune system in children with Down syndrome: a review. Clin. Exp. Immunol. 156: 189-193. https://doi.org/10.1111/j.1365-2249.2009.03890.x

Lorenzo LP, Shatynski KE, Clark S, Yarowsky PJ, et al. (2013). Defective thymic progenitor development and mature T-cell responses in a mouse model for Down syndrome. Immunology 139: 447-458. https://doi.org/10.1111/imm.12092

Murphy M, Friend DS, Pike-Nobile L and Epstein LB (1992). Tumor necrosis factor-alpha and IFN-gamma expression in human thymus. Localization and overexpression in Down syndrome (trisomy 21). J. Immunol. 149: 2506-2512.

Pellegrini FP, Marinoni M, Frangione V, Tedeschi A, et al. (2012). Down syndrome, autoimmunity and T regulatory cells. Clin. Exp. Immunol. 169: 238-243. https://doi.org/10.1111/j.1365-2249.2012.04610.x

Pena SD, Di Pietro G, Fuchshuber-Moraes M, Genro JP, et al. (2011). The genomic ancestry of individuals from different

Genetics and Molecular Research 16 (3): gmr16039738 
geographical regions of Brazil is more uniform than expected. PLoS One 6: e17063.

Salazar LA, Hirata MH, Cavalli SA, Machado MO, et al. (1998). Optimized procedure for DNA isolation from fresh and cryopreserved clotted human blood useful in clinical molecular testing. Clin. Chem. 44: 1748-1750.

Schoch J, Rohrer TR, Kaestner M, Abdul-Khaliq H, et al. (2017). Quantitative, phenotypical and functional characterization of cellular immunity in pediatric individuals with Down syndrome. J. Infect. Dis. 215: 1619-1628. https://doi. org/10.1093/infdis/jix168

Shin KK, Jang Y, Koh SJ, Chae JS, et al. (2007). Influence of the IL-6 $-572 \mathrm{C}>\mathrm{G}$ polymorphism on inflammatory markers according to cigarette smoking in Korean healthy men. Cytokine 39: 116-122. https://doi.org/10.1016/j. cyto.2007.06.005

Silva CR, Biselli-Périco JM, Zampieri BL, Silva WA, Jr., et al. (2016). Differential Expression of Inflammation-Related Genes in Children with Down Syndrome. Mediators Inflamm. 2016: 6985903. https://doi.org/10.1155/2016/6985903

Sommer CA, Pavarino-Bertelli EC, Goloni-Bertollo EM and Henrique-Silva F (2008). Identification of dysregulated genes in lymphocytes from children with Down syndrome. Genome 51: 19-29. https://doi.org/10.1139/G07-100

Teixeira GF, Mendonça SA, Menezes Oliveira K, Barbosa Dos Santos D, et al. (2014). Interleukin-6 c.-174G $>$ C Polymorphism and Periodontitis in a Brazilian Population. Mol. Biol. Int. 2014: 490308. https://doi. org/10.1155/2014/490308

Trotta MBF 2009 Mecanismos inflamatórios e imunológicos na síndrome de Down, Doctoral thesis. Universidade de São Paulo USP. Faculdade de Medicina. São Paulo.

Tsilingaridis G, Yucel-Lindberg T and Modéer T (2003). Enhanced levels of prostaglandin E2, leukotriene B4, and matrix metalloproteinase-9 in gingival crevicular fluid from patients with Down syndrome. Acta Odontol. Scand. 61: 154158. https://doi.org/10.1080/00016350310002270

Tsilingaridis G, Yucel-Lindberg T and Modéer T (2012). T-helper-related cytokines in gingival crevicular fluid from adolescents with Down syndrome. Clin. Oral Investig. 16: 267-273. https://doi.org/10.1007/s00784-010-0495-6

Vicari P, Adegoke SA, Mazzotti DR, Cançado RD, et al. (2015). Interleukin-1 $\beta$ and interleukin-6 gene polymorphisms are associated with manifestations of sickle cell anemia. Blood Cells Mol. Dis. 54: 244-249. https://doi.org/10.1016/j. bcmd.2014.12.004

Wang CY, Liang CY, Feng SC, Lin KH, et al. (2017). Analysis of the Interleukin-6 (-174) Locus Polymorphism and Serum IL-6 Levels with the Severity of Normal Tension Glaucoma. Ophthalmic Res. 57: 224-229. https://doi. org $/ 10.1159 / 000455152$

Zampieri BL, Biselli-Périco JM, de Souza JE, Bürger MC, et al. (2014). Altered expression of immune-related genes in children with Down syndrome. PLoS One 9: e107218. https://doi.org/10.1371/journal.pone.0107218

Zhang J-M and An J (2007). Cytokines, inflammation, and pain. Int. Anesthesiol. Clin. 45: 27-37. https://doi.org/10.1097/ AIA.0b013e318034194e

Zhang T, Wang Z and Xiao W (2017). A meta-analysis of interleukin-6 -572G $>$ C polymorphism and coronary heart disease susceptibility. Cardiol. J. 24: 107-110. https://doi.org/10.5603/CJ.2017.0008

Genetics and Molecular Research 16 (3): gmr16039738 